\title{
Assignment integration in order to achieve the successful studio- based education

\author{
(An Idea Implementation of Integrated Architecture Experiential Learning)
}

\author{
Yaseri D. Apritasaria ${ }^{\mathrm{a}}$, Doni Fireza ${ }^{\mathrm{a}}$

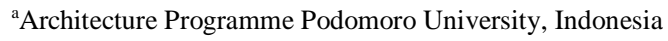 \\ E-mail address: yaseri.apritasari@ podomorouniversity.ac.id
}

\begin{abstract}
The formal architecture undergraduate degree (S1) is determined by taking total 144 credits, in 8 semesters (4 years). After he/she graduated and earn the B.Arch, to become a professional architect one must take 1-2 year's professional diploma including internship in one architectural bureau. All this limitations may cause several strategies such as a curriculum adjustment in order to meet all the teaching materials needed. Those strategies includes; eliminating some subjects that considered not necessary, decreasing the teaching materials content in order to create lesser credits so more subjects may be added into the curriculum, or merging some subjects into a new subject and adding more credits into it. This condition affecting the learning objective of the new subject cannot be achieved optimally. Seeing this tendency, an idea has emerged by integrating some of the subjects' assignments into one comprehensive assignment. This concept is derived into scenarios that a student will undergo a one big assignment containing materials from several subjects, and the scoring phase will be examined from several subjects' point of views. This paper will discuss the effectiveness of architecture subject assignment integration, in this case the architecture design studio as the core of architecture education with other supporting subjects including the theoretical subjects, to achieve architecture education's target and objective. Methodology of research used is qualitative research through observation methods: (1) Condition of the studio assignments with other supporting subjects (theory and skill) assignments that can be integrated, (2) Strategy to achieve the learning objective target through the integration of the studio assignments with other subjects' assignments, (3), Advantage and disadvantage of the assignments' integration scenario. Hopefully the result of the integration of the studio assignments with other subject's assignments can achieve the successful architecture education, effective, target fulfilled, and optimized.
\end{abstract}

Keywords: integrated assignment; architecture design studio; architecture education

\section{Background}

Architecture education in Indonesia now is facing another phase. After went through the changes of nomenclature of the undergraduate degree in 1996 - from Insinyur to Sarjana Teknik (B. Arch), the formal undergraduate degree (S1) is determined by taking total at least 144 credits in 8 semesters ( 4 years). This changes was following the reduction of the credit course that an Insinyur must took, 160 credits for 10 semesters. This cause the previous architecture education system that was trying to generate the professional qualification becoming the graduates that was ready to be developed to become professionals.

These graduates are not "ready to practice" architects. After he/she graduated and earn the B.Arch, to become a professional architect one must take 1-2 years professional diploma including internship in one architectural bureau. However, for those who don't wish to become a professional architect, they can use their undergraduate degree to work in other fields, or even in a field that related to architecture. This condition is also endorsed by the Indonesian 
Institute of Architects (Ikatan Arsitek Indonesia, 2015) which at least for the last 8 years has tried to appeal the new legislation for regulating the architect's profession in Indonesia.

So, in order to meet all the requirements that this new legislation stated, all the stakeholders that related to the architecture education must make any preparation needed. Including the universities that conducting the architecture department. They are aware that throughout all these processes in making an architect, the success of the first stage is a really important. How to make an effective but efficient education system is pursued. New teaching methods are introduced and tested. In order to meet the quality qualification standards issued by the accreditation board (BANPT), many strategies were applied. Studying architecture must be in accordance with the curriculum schedule and on time graduation becoming a goal that a university must achieve. Studying architecture, which often be associated to long hours and sleepless nights assignments are tried to simplify without leaving the learning outcomes behind.

All these demands may cause several strategies such as a curriculum adjustment in order to meet all the teaching materials needed for an undergraduate degree in architecture.

Those strategies include;

(1) Eliminating some subjects that considered not necessary. This strategy was intended to make the students to be more focus in subject that strongly related to architecture or design process. Concerning that each project is involving many disciplines, so those subjects that strongly related to other disciplines are considered can be eliminated.

(2) Modifying the teaching materials or the subject's credits. In contrary with the previous strategy, this strategy is decreasing the teaching materials content in order to create lesser credits so more subjects may be added into the curriculum. By lessen the teaching materials in one subjects, caused the weight of the subject decreased, so the learning objective can be lower resulting the subject can be more "easy" for the students. This strategy is also accompanying with the introduction of new other "light" subjects into the curriculum to meet the recent issues.

(3) Merging some subjects into a new subject and adding more credits into it. Sometimes, the educators think that not all the teaching materials of a subject needed to be studied. By taking some of the related materials and merge it into a new subject is considered more effective and efficient for students to study. However, this action may cause the weight of the subject to increase. Adding more credits is a must. This strategy may result to the distribution of the subjects in the curriculum. One semester may contain fewer subjects compared to other universities but with the same total credits offered. This strategy is also has weakness. Having various types of teaching materials in one subject affecting the learning objectives of the new subject cannot be achieved optimally.

With all these strategies applied to the management of architecture education system in one institution, the big question is still hanging. Is the learning outcomes of the architecture education can be achieved effectively and efficiently? Are these strategies can affect to study architecture in undergraduate level to be completed on schedule?

Seeing this tendency, a new idea has emerged by integrating some of the subjects' assignments into one comprehensive assignment. This concept of idea is derived into scenarios that a student will undergo a one big assignment containing materials from several subjects, and the scoring phase will be examined from several subjects' point of views. In other words, several different lecturers from all different subjects that the student took in one semester will examine the assignment. Of course, this examination will meet all the criteria according to each subject's syllabus.

This action ideally may make the students more focus into one case study or projects to be completed in one assignment in one semester. By integrating the assignment, one study case/project may cover all the subjects' learning objectives which to be achieved. The thinking process, research needed, and producing the product to complete one assignment may more efficient and effective if this concept is executed in ideal condition.

\section{Research theory and methods}

Architecture education is a unique and complex education. As known, because it is associated with planning, designing and operating of a container and a place of human activity, then it will touch all aspects of other disciplines. Especially when associated with the typology of the functions that will be placed.

Various sources state that the architecture is a major discipline because it studies all of aspects of human life. While Wayne Attoe, a Professor of Architecture in Architecture Criticism has opinion that the nature of science of architecture is doubtful due to it don't touch the foundations of other scientific fields such as philosophy, language, social, religious, etc. It makes the architectural education is unique, because in addition to sufficient reasoning 
ability is required, the ability of intuition and aesthetic sense, and also the ability to criticize something are necessary for the architecture students.

Architectural education is professional education. Despite the fact that some research says that no more than $10 \%$ of architectural graduates have a profession as an architect. In fact, according to the head of the Department of Architecture at the University of Indonesia Andri Yandri Yatmo, only about 50\% of UI architecture's alumni that works in the field of architecture. However, no matter there is a significant difference between the objectives, the method and the results of architectural education products, the education pattern and system towards the architect profession continues to be applied all over the world.

The core of architecture education is known based on the design studio. The pattern of architecture design studio education can be expressed as a process exemplifies the position and the value of a conceptual designer on a case / project. UIA - UNESCO Charter for Architectural Education stated that the main purpose of architecture education is to form students with the capacity to conceptualize, design, understand, and be aware of the rules of the building, in a practical context. Moreover, seeing the world related to the case / project from the perspective of one person in this case the students itself is happening in studio.

Studio is the king of subjects in architectural education. In a studio the application of knowledge about the building and its surroundings takes place, as well as where design activity occurs. This capacity along with the balance among emotion, reason, and intuition work together in shaping the physical form of human needs. Embodiments towards the establishment of the students with the capacity above, the studio teaching should be a major part in the learning process. Individual project under the guidance of lecturers / assistant lecturers more strongly encouraged and is a synthesis of the mastering the knowledge and skills required. Gross states that the project-based design studio is a form of architecture education that has become part of the tradition. In campus, the supporting subject that offered in parallel with the design studio also takes place. Challenges that arise in the project-based studio method are how to integrate the lecture-based supporting subject teaching materials with the learning experience-based design studio.

Studio-based education requires the activeness of the students. Because in design studio, students are active learners and instructions are given directly and centered on the student. In terms of educational psychology, (Slavin, 2003) states that this learning method is categorized as Constructivists Theory of learning where the learner must individually discover and transform information that is complex, checking new information against the rules and revise the regulation when it is no longer apply. Constructivists theory concerned with the principle that students must build a structure of knowledge in his mind, which lecturers act as facilitators. Lecturers also act as mentors in addition to the learning activities and not as commanders in the field who ruled only by instructions.

From here, the transfer of knowledge can be formed by the way of cognitive apprenticeship. In this way, students gradually gain knowledge and skills of something that must be mastered through interaction with experts (professors) or other resources. In the execution of a project / case study in architectural design studio, then apply a top-down processing. Top-down processing is educational activity, which begins with the appearance of the main problems, then break it down into small problems and find ways to solve through the counseling process (Slavin, 2003). Ideally, the design process is directed on the form of self-regulates learning, which is the ideal form of constructivist theory (Slavin, 2003). This is a continuation of the top-down processing in which testing the alternatives solutions as a result of solving the little problems that emerged. Obstacles that may arise from this form of learning is that the limit the success of a project is the satisfaction of the students rather than on the assessment or approval of a supervisor. In architecture design studio, which has a certain time limit - usually 1 semester - for a single project, it is rather difficult to applied.

In reaching the architecture student with capacity that is produced by an architectural education, then each subject must have learning objectives to be achieved for each process. From the recommendation of learning outcomes that to be achieved by architect profession compiled by the Indonesia's Association of Architecture Higher Education (APTARI) and Indonesian Institute of Architects (IAI) generally indicates that the profession of architect, and a bachelor's degree / master of architecture, or architectural education graduates must master some aspects such as attitudes, knowledge, skills, general and specific that are desired to be achieved by each learners in architectural education. The distribution and the arrangement of subjects for each semester need to be carefully considered in order to conform with the purpose of learning outcomes desired by APTARI and IAI. In addition, the preparation of 
each course syllabus and course outlines (SAP) as the operational form of learning needs to be designed so that the main purpose of architectural education can be achieved effectively.

\section{Results and discussion}

\section{Conditions of architecture design studio and other supporting subjects (theory and praxis)}

Architecture education has a complete learning objective. The main achievements of its students are the possession ability to design, having supporting capabilities such as cultural and artistic studies, social studies, environmental studies, technical studies, design studies and professional studies, as well as other soft skills. Architecture design studio becomes the core subjects where all of the learning objectives gathered here with other subjects in the curriculum serves as the supporting subject. Successful result of the architectural design studio shows the ability of the design process by mastering the spatial experience comprehension skill, supported knowledge, social studies, environmental studies, technical studies, design studies and professional studies. The three learning objectives of the architecture student that has to be achieved can be seen in table 1.1

Tabel 1.1 Architecture education competency

Source :UIA, 2011

\begin{tabular}{lll}
\hline Capability & Remark & \multicolumn{1}{c}{ Detail } \\
\hline DESIGN & - & Ability to engage imagination, think creatively, \\
& innovate and provide design leadership. \\
& Ability to gather information, define problems, apply \\
& analyses and critical judgement and formulate strategies \\
& for action. Ability to think three-dimensionally in the \\
& exploration of design.
\end{tabular}

- Ability to reconcile divergent factors, integrate knowledge and apply skills in the creation of a design solution.

KNOWLEDGE Cultural and Artistic - Ability to act with knowledge of historical and cultural Studies $\quad$ precedents in local and world architecture.

- Ability to act with knowledge of the fine arts as an influence on the quality of architectural design.

Social Studies

- Ability to act with knowledge of society, and to work with clients and users that

- Represent

- society's needs.

- Ability to develop a project brief through definition of the needs of society users and clients, and to research and define contextual and functional requirements for different types of built environments.

- Understanding of the social context in which built environments are procured, of ergonomic and space requirements and issues of equity and access.

- Awareness of the relevant codes, regulations and standards for planning, design, construction, health, safety and use of built environments.

- Awareness of philosophy, politics, and ethics as related to architecture.

Environmental $\quad-\quad$ Ability to act with knowledge of natural systems and Studies built environments.

- Understanding of conservation and waste management issues.

- Understanding of the life cycle of materials, issues 
Technical Studies

of ecological sustainability, environmental impact, design for reduced use of energy, as well as passive systems and their management.

- Awareness of the history and practice of landscape architecture, urban design, as well as territorial and national planning and their relationship to local and global demography and resources.

- Awareness of the management of natural systems taking into account natural disaster risks.

- Technical knowledge of structure, materials, and construction.

- Ability to act with innovative technical competence in the use of building techniques and the understanding of their evolution.

- Understanding of the processes of technical design and the integration of structure, construction technologies and services systems into a functionally effective whole.

- Understanding of services systems as well as systems of transportation, communication, maintenance and safety.

- Awareness of the role of technical documentation and specifications in design realisation, and of the processes of construction, cost, planning and control.

Design Studies $\quad$ - Knowledge of design theory and methods.

- Understanding of design procedures and processes.

- Knowledge of design precedents and architectural criticism

Professional Studies - Ability to understand different forms of procurement of architectural services.

- Understanding of the fundamental workings of the construction and development industries, such as finance, real estate investment and facilities management.

- Understanding of the potential roles of architects in conventional and new areas of activity and in an international context.

- Understanding of business principles and their application to the development of built environments, project management and the functioning of a professional consultancy.

- Understanding of professional ethics and codes of conduct as they apply to the practice of architecture and of the architects' legal responsibilities where registration, practice and building contracts are concerned.

SKILL

1. Ability to work in collaboration with other architects and members of interdisciplinary teams.

2. Ability to act and to communicate ideas through collaboration, speaking, numeracy, writing, drawing, modelling and evaluation.

3. Ability to utilize manual, electronic, graphic and model 
making capabilities to explore, develop, define and communicate a design proposal.

4. Understanding of systems of evaluation, that uses manual and/or electronic means for performance assessments of built environments.

With the limitation of credits and the high demands of complex learning objectives, one of the efforts taken is to integrate the tasks from several courses related. This to optimize the ability of students with efficient and effective time consumption and all the supporting subjects can be applied. Students are becoming more understood and learning objectives can be achieved.

\section{Strategy to achieve the learning objective target}

Strategy to achieve the target of learning objectives through the integration of the studio assignments with other subjects are:

1. Looking the intersection of learning outcomes between supporting course subject (theory and praxis) and architecture design studio subject courses.

2. Coordinating weekly course outlines and assignment's terms of reference among lectures of supporting course subject (theory and praxis) and architecture design studio courses subject.

3. Choosing only the most required tasks product.

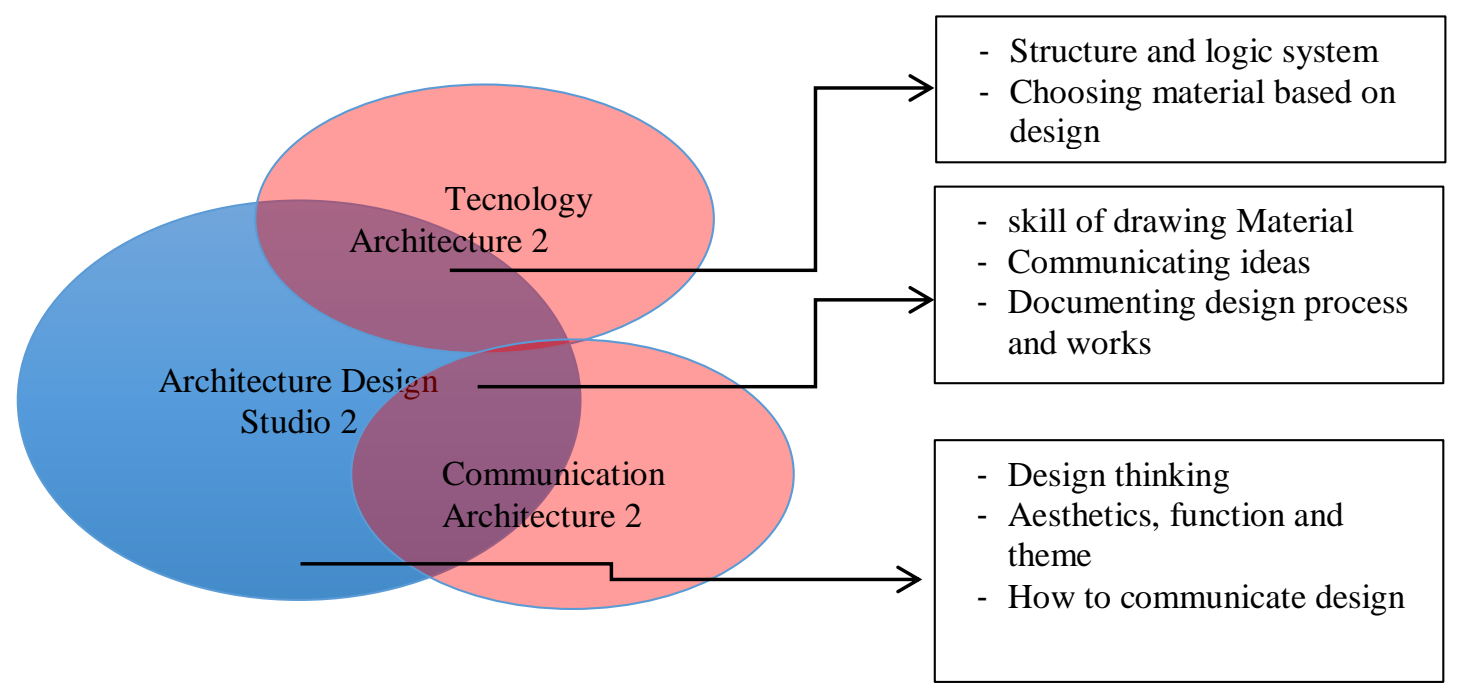

Fig. 1. Over lay learning outcomes among 3 subjects.

Two or three courses can be integrated into a single assignment with the focus and the largest percentage of concentration is for the subject of Architecture Design Studio. For example, subjects in semester 2 like Architecture Design Studio 2 (ADS2), is integrated with courses like the Architecture Communication Technique 2 (ACT2) and Architecture Technology Environment 2 (ATE2). The assignment is loaded with the learning outcomes of all three of these courses. Good coordination between these subjects is necessary. The supporting course material from ACT2 and ATE2 can be given parallel with the process of ADS2.

For example, given course material such as the method of making the concept diagram presentation from ACT2, has to be applied in panels that show the design concept in ADS2 project. Similarly to the ATE2 course material that study the concept of the structure and how to make working drawings has to be applied in presenting drawing of ADS2. So there is no specific assignment from ACT2 and ATE2 needed to test the comprehension of the students about these course materials. The rhythm among these course materials should be kept harmonious and the 
lecturers have to make sure that the students have fully understood about these course materials so they can apply them into their design.

In addition to coordination between these subjects, it also takes full commitment and discipline from the students. Because these courses share the same relevance, so the process of this needs mutual support and understanding. If the process in ADS2 could not be completed, it may impact on other subject.

Table 2. Integration assignment for 3 subject courses

\begin{tabular}{|c|c|c|c|c|}
\hline \multirow[t]{2}{*}{ Subject } & \multirow{2}{*}{\multicolumn{2}{|c|}{ Learning outcome }} & \multicolumn{2}{|c|}{ Product } \\
\hline & & & Partial assignment & Integrated assignment \\
\hline $\begin{array}{l}\text { Architecture } \\
\text { Communication } \\
\text { Technique } 2\end{array}$ & - & $\begin{array}{l}\text { To explore and } \\
\text { encourage the act and } \\
\text { skill of drawing and its } \\
\text { value to the architect. } \\
\text { Delivering dynamic } \\
\text { renderings techniques } \\
\text { for architectural } \\
\text { presentation } \\
\text { Performing a design } \\
\text { process through } \\
\text { analytical and } \\
\text { conceptual diagrams. } \\
\text { Communicating ideas } \\
\text { through experimental } \\
\text { drawing techniques. } \\
\text { Delivering oral and } \\
\text { drawing presentation of } \\
\text { an Architectural project } \\
\text { / observation } \\
\text { Documenting design } \\
\text { process and works in a } \\
\text { architectural portfolio. } \\
\text { Understanding } \\
\text { correlation between } \\
\text { function and user } \\
\text { Understanding activity } \\
\text { programme } \\
\text { Understanding } \\
\text { transformation from } \\
\text { activity programme to } \\
\text { mass composition. } \\
\text { Mastering the } \\
\text { transformation of } \\
\text { programming activity } \\
\text { into mass composition } \\
\text { Imagination about } \\
\text { space, shape and form. } \\
\text { Understanding the } \\
\text { phenomenon and the } \\
\text { issues that arise around } \\
\text { the building. }\end{array}$ & $\begin{array}{ll}\text { - } & \text { Portfolio panel: } \\
\text { assembling ideas } \\
\text { - } & \text { Ortographic } \\
\text { rendering } \\
\text { - } & \text { Diagrams: } \\
\text { diagramming as } \\
\text { design } \\
\text { communication } \\
\text { - } & \text { Two dimensional } \\
& \text { diagrams } \\
\text { - } & \text { Three dimensional } \\
& \text { diagrams } \\
\text { - } & \text { Architectural } \\
& \text { portfolio } \\
\text { - } & \text { Digital portfolio }\end{array}$ & $\begin{array}{l}\text { Products of the } \\
\text { Assignment of } \\
\text { Architecture Design Studio } \\
\mathbf{2} \\
\text { - Data and problem } \\
\text { identify (Arch Comm2) } \\
\text { - Activity and function } \\
\text { Diagram (Arch Comm2) } \\
\text { - Concept of Form } \\
\text { transformation process } \\
\text { (activity program to mas } \\
\text { composition) (Arch } \\
\text { Comm) (Arch } \\
\text { Design criteria (plan, } \\
\text { Comm) plan } \\
\text { Work section) } \\
\text { elevation, sective } \\
\text { Perspective } \\
\text { (Architecture } \\
\text { Technology } \\
\text { Environment 2) }\end{array}$ \\
\hline
\end{tabular}




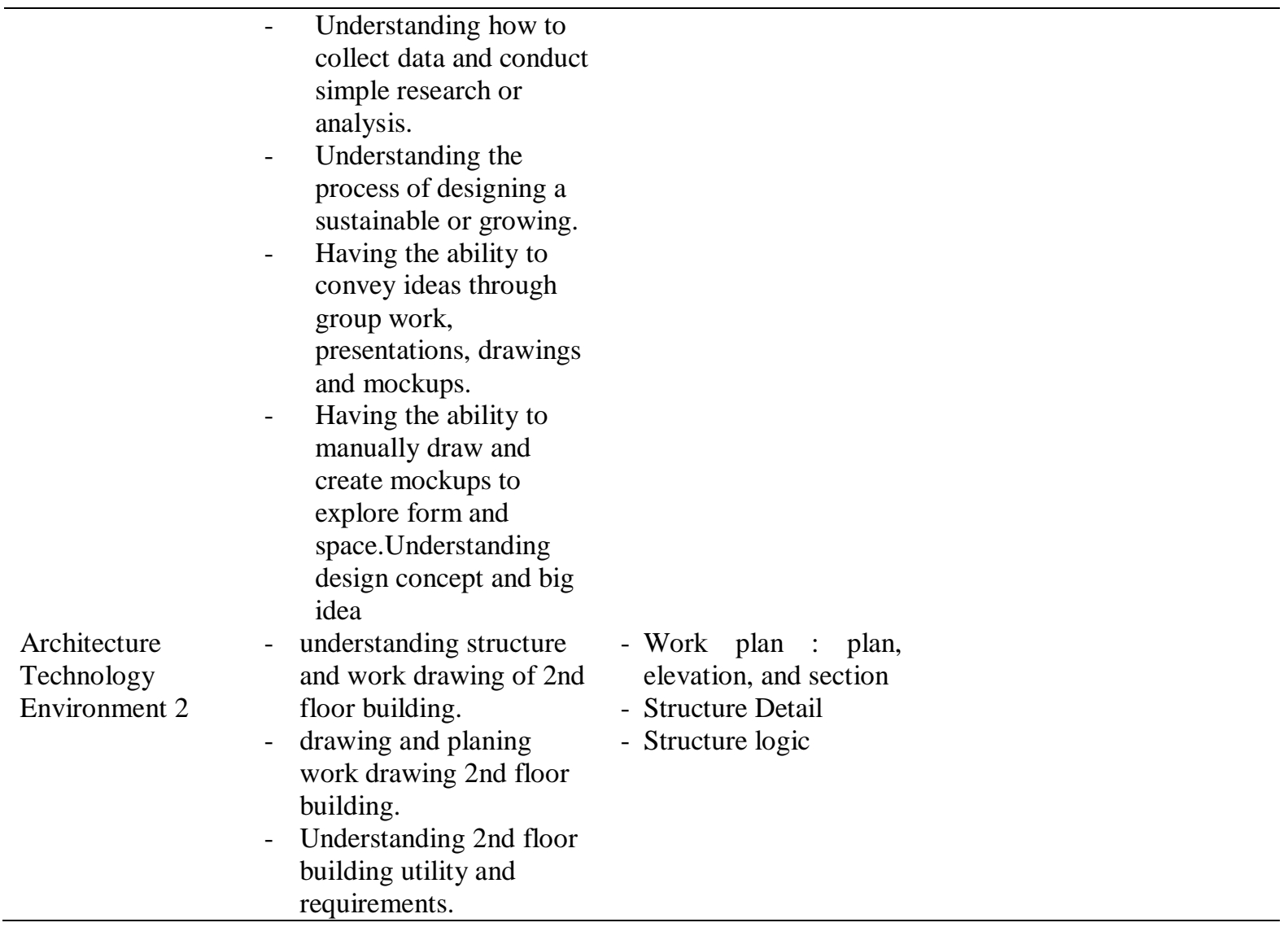

From the table above shows that the art, social studies, communication skill, and technical aspects can be directly applied in the design studio assignment. How to present the concept of design can be examined within the frame of ACT2 subject, while the making of structural concept and the working drawings can be scored as the ATE2 assignment.

\section{Advantage and disadvantage of the assignments' integration scenario}

As described earlier, the advantage of integrate these assignment, is to save time and energy in achieving the target of student learning outcomes. Students focus work on products that match the learning outcomes.

Coordination and commitment from both between subjects are important, because these subjects are interrelated and interdependent to one another. Theory and praxis subject will be immediately applied in the task in the studio. But the demands of the ability in the studio must be fulfilled in theory and praxis classes. Weekly course outline and project term of reference should have been planned for integration from the start, but in the process of its implementation can be flexible according to the needs.

The flexible weekly course outline is beneficial and ensures students understand course material properly. However, this can make the learning outcomes of these courses is not achieved due to the condition of the ability of students' understanding of the achievements of learning outcomes. Students' understanding of the subjects will have an impact on other subjects. Another effect is that if one task is failed, can affect the success of other task from other integrated subjects. 


\section{Conclusions}

Strategies of integrated assignment in order to achieve optimum learning objectives are:

1. Choosing the same learning outcomes that intersect from subjects and put them into one integrated assignment.

2. Coordination among weekly course outline from every subjects and committed and discipline in running them.

From the description above, the advantages and disadvantages of the strategies of integrated assignment are:

Table 3. Advantage and disadvantage of integrated assignment

\begin{tabular}{|c|c|c|}
\hline & Advantage & Disadvantage \\
\hline 1 & $\begin{array}{l}\text { Students can directly implement design } \\
\text { theory in design }\end{array}$ & $\begin{array}{l}\text { When students take courses that } \\
\text { are not parallel, the task becomes } \\
\text { heavy. }\end{array}$ \\
\hline 2 & $\begin{array}{l}\text { Coordination between subjects can fill in } \\
\text { the blanks that may occur in one subject } \\
\text { and can complement each other. }\end{array}$ & $\begin{array}{l}\text { Some phase of process is } \\
\text { supposed to wait for other course } \\
\text { material of other subjects to } \\
\text { completely given before can } \\
\text { proceed to completion }\end{array}$ \\
\hline 3 & $\begin{array}{l}\text { The time needed is more optimal for } \\
\text { integrated assignment and more focus on } \\
\text { the mastering the course material }\end{array}$ & $\begin{array}{l}\text { Dependency among integrated } \\
\text { subjects are high }\end{array}$ \\
\hline 4 & $\begin{array}{l}\text { The value of the assignment can be } \\
\text { maximized for related subjects }\end{array}$ & $\begin{array}{l}\text { If one assignment failed, then the } \\
\text { score of the other integrated } \\
\text { courses are also failed }\end{array}$ \\
\hline
\end{tabular}

\section{References}

Ikatan Arsitek Indonesia. (2015). Penyusunan Standar Pendidikan, Kurikulum, dan Capaian Pembelajaran (Learning Outcomes) Pendidikan Profesi Arsitek. Jakarta.

Slavin, R. E. (2003). Educational psychology : theory and practice (7th ed.). Boston: Allyn and Bacon. 

-This page intentionally left blank-

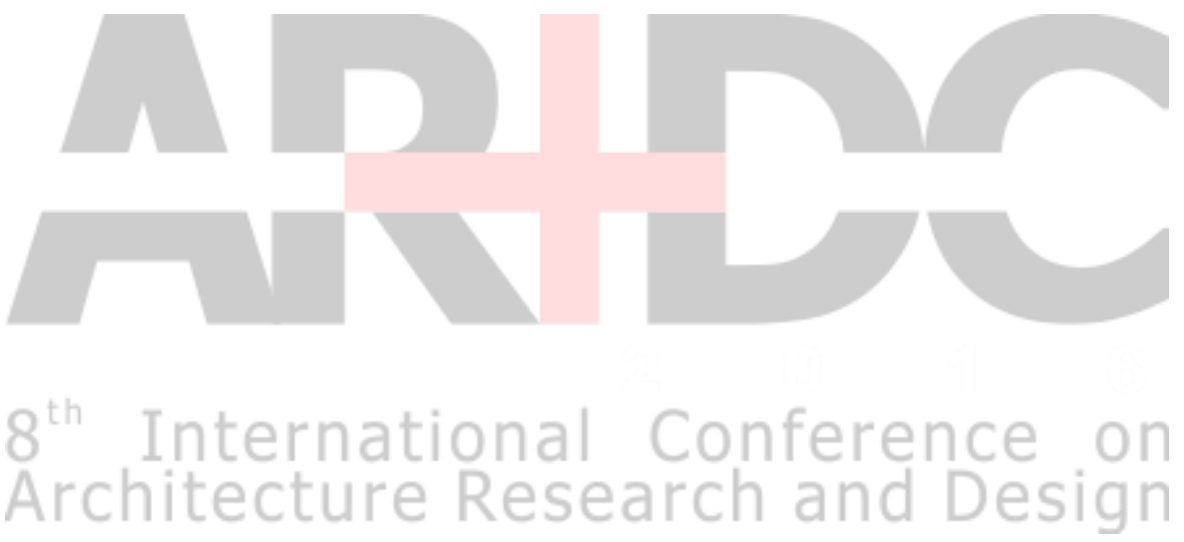

